\title{
Pendekatan One Village One Product (OVOP) untuk Mengembangkan Potensi Kerajinan Daerah Studi Kasus: Kerajinan Gerabah di Kecamatan Plered, Kabupaten Purwakarta
}

\author{
Meirina Triharini, Dwinita Larasati \& R. Susanto \\ Program Studi Magister Desain Fakultas Seni Rupa dan Desain, \\ Institut Teknologi Bandung, Jl. Ganesa 10, Bandung 40132, Indonesia \\ Email: meirinatriharini@yahoo.com
}

\begin{abstract}
Abstrak. One Village One Product (OVOP) adalah suatu pendekatan pembangunan daerah yang bertujuan untuk memajukan ekonomi daerah tersebut. Konsep OVOP berasal dari Oita, Jepang dan diadopsi oleh berbagai negara di dunia. Indonesia melalui Kementerian Perindustrian sejak tahun 2008 melaksanakan program OVOP yang bertujuan untuk memajukan potensi industri kecil dan menengah kerajinan di sepuluh wilayah di Indonesia, termasuk Purwakarta dengan potensi kerajinan gerabah dan keramik hias. Penerapan OVOP dalam rangka memajukan industri kerajinan memerlukan strategi yang sesuai dengan prinsip mendasar OVOP dan dapat menyelesaikan permasalahan yang dihadapi oleh industri produk kerajinan di daerah sasaranPenelitian ini bertujuan untuk mengevaluasi penerapan OVOP di Indonesia yang telah berlangsung sejak tahun 2008 dan menyusun sebuah rekomendasi bagi pengembangan potensi produk kerajinan dengan pendekatan OVOP dengan mengambil studi kasus di Plered, Purwakarta. Rekomendasi ditujukan bagi pemerintah sebagai pemangku kebijakan, masyarakat sebagai pelaksana, dan pihak swasta, khususnya akademisi desain atau desainer professional.Selain pentingnya konsistensi pemerintah dan partisipasi masyarakat dalam melaksanakan dan mengawasi berjalannya program yang telah disusun, pengembangan desain produk kerajinan memegang peranan yang sangat penting. Diperlukan peran desainer yang sangat kuat untuk dapat mengembangkan desain yang dapat memahami kebutuhan pasar sekaligus mempertahankan nilai-nilai tradisional kerajinan dan menyelesaikan permasalahan yang dihadapi oleh industri.
\end{abstract}

Kata kunci: gerabah; kerajinan; keramik; OVOP; Purwakarta.

Abstract. One Village One Product (OVOP) is a regional development approach that aims to promote the economy of a region. The concept of OVOP was origined from Oita, Japan, and adopted by various countries in the world. Indonesia through the Ministry of Industry since 2008 implementing OVOP program that aims to promote the potential of small and medium craft industry in the ten regions in Indonesia, including Purwakartawith its potential on decorative pottery and ceramic crafts. This study aims to evaluate the implementation of

Received September $3^{\text {rd }}, 2012$, Revised Desember $10^{\text {th }}, 2013$, Accepted for publication January $7^{\text {th }}, 2014$. Copyright () 2014 Published by LPPM ITB, ISSN: 1978-3078, DOI: 10.5614/itbj.vad.2014.6.1.4 
OVOP in Indonesia that has been ongoing since 2008 and make a recommendation for the development of potential handicrafts with OVOP approach by taking a case study in Plered, Purwakarta. In addition to the importance of consistency of government and public participation and oversight in implementing the program, the development of craft product design plays a very significant role. It is required for designers to have very strong roles to develop designs that can understand the market needs while maintaining the traditional values of craft and resolve the problems faced by the industry.

Keywords: craft; ceramic; OVOP; pottery; Purwakarta.

\section{Pendahuluan}

Pendekatan One Village One Product (OVOP) pertama kali diinisiasi di Oita, Jepang, OVOP merupakan suatu pendekatan pengembangan potensi daerah di satu wilayah untuk menghasilkan produk yang mampu bersaing di pasar global, dengan tetap memiliki ciri khas keunikan karakteristik dari daerah tersebut. Produk yang dihasilkan adalah produk yang memanfaatkan sumber daya lokal, baik sumber daya alam, maupun sumber daya manusia.

Penerapan OVOP di Indonesia dilaksanakan melalui program Kementerian Perindustrian sejak tahun 2008 untuk mengembangkan potensi industri kecil dan menengah pada berbagai sektor, termasuk di antaranya sektor kerajinan [1]. Sepuluh wilayah yang dipilih oleh Pemerintah untuk dikembangkan dengan pendekatan OVOP yaitu: Purwakarta (gerabah/keramik hias); Tasikmalaya (anyaman); Pekalongan (tenun dan anyaman akar wangi); Boyolali (kerajinan tembaga); Bantul (gerabah/keramik hias); Kulonprogo (anyaman); Bangli (anyaman bambu); Tabanan (gerabah/keramik hias); Lombok Barat (gerabah/keramik hias); dan Lombok Tengah (anyaman rotan dan ate). Kesepuluh wilayah ini dipilih berdasarkan potensi kerajinan dan penelitian awal mengenai kompetensi inti daerah yang dapat dikembangkan lebih lanjut. Proses ini sepenuhnya dilaksanakan oleh pemerintah dengan bantuan konsultan sebagai pihak ketiga. Wilayah yang menjadi objek studi kasus dalam penelitian ini adalah wilayah yang terdapat di Jawa Barat yaitu Purwakarta dengan produk kerajinan utama gerabah atau keramik hias. Wilayah Purwakarta dipilih sebagai studi kasus pada penelitian ini karena gerabah atau keramik hias di Purwakarta sudah dikenal sejak 1795 dan masih bertahan hingga saat ini. Selain itu terdapat pula beberapa penelitian terdahulu yang mengkaji perkembangan industri gerabah di Purwakarta yang dapat dijadikan sebagai landasan dalam membandingkan kondisi industri sebelum dan sesudah dilaksanakan program OVOP.

Pengembangan desain produk kerajinan pada berbagai wilayah ini merupakan salah satu aspek dari keseluruhan aspek yang terkait dalam pendekatan OVOP 
untuk mengembangkan potensi suatu daerah. Oleh karena itu diperlukan suatu strategi yang mencakup keseluruhan aspek terkait. Aspek-aspek yang menjadi faktor penentu keberhasilan OVOP diidentifikasi melalui studi literatur mengenai penerapan OVOP di negara asalnya yaitu Jepang sebagai acuan, dan penerapan OVOP di berbagai negara, khususnya di Asia, sebagai pembanding.

\section{$2 \quad$ Metode Penelitian}

Penelitian yang dilakukan merupakan penelitian kualitatif yang bersifat eksploratif dan evaluatif. Penelitian eksploratif dilakukan dengan tujuan untuk mengetahui informasi yang lebih jauh dan lebih dalam mengenai konsep-konsep OVOP, baik dari sejarah awalnya di Oita, Jepang maupun perkembangan penerapannya di beberapa negara lainnya. Penelitian ini juga dilakukan karena minimnya penelitian yang menguraikan tentang penerapan OVOP di Indonesia, meskipun program ini telah banyak dilaksanakan di berbagai daerah sejak tahun 2008, khususnya untuk sektor kerajinan.

Penelitian evaluatif dilakukan untuk mengetahui hasil pelaksanaan OVOP yang telah dilakukan di Indonesia, dengan mengambil sebuah contoh kasus yaitu Purwakarta, Jawa Barat. Tujuan lain dari dilakukannya penelitian evaluatif ini adalah untuk mengetahui sejauh mana atau seberapa tinggi tingkat efektivitas setiap faktor, unsur, atau komponen dalam mendukung pelaksanaan program untuk mencapai tujuan dari penerapan OVOP itu sendiri.

Program OVOP di Purwakarta yang dijadikan studi kasus pada penelitian ini merupakan program pemerintah yang dilaksanakan oleh Kementerian Perindustrian pada tahun 2008-2009 lalu. Program ini melibatkan tiga pihak utama yaitu pemerintah, Tim ahli, dan masyarakat daerah itu sendiri [2]. Oleh karena itu, maka perlu diketahui terlebih dahulu aspek-aspek yang dapat mempengaruhi keterlaksanaan OVOP agar dapat dijadikan sebagai parameter pembanding. Parameter didapatkan melalui studi literatur dan hasil survey lapangan. Keberhasilan diindikasikan dengan tercapainya tujuan utama dari OVOP.

\section{$3 \quad$ Hasil}

One Village One Product (OVOP) pertama kali dicetuskan oleh Morihiko Hiramatsu saat menjabat sebagai Gubernur Perfektur Oita di timur laut Kyushu, Jepang. Selama 6 periode (24 tahun) masa jabatannya, Morihiko Hiramatsu mengentaskan kemiskinan warganya dengan menerapkan konsepsi pembangunanwilayah yang Ia cetuskan itu. Gerakan OVOP kemudian secara pesat memberikan kontribusi sangat besar bagi pembangunan regional di Perfektur Oita. 
OVOP bertujuan untuk mengembangkan produk yang mampu bersaing di pasar global dengan tetap menekankan pada nilai tambah lokal dan mendorong semangat menciptakan kemandirian masyarakat. Ketika itu OVOP dicanangkan sebagai kebijakan dalam rangka mengatasi masalah depopulasi yang disebabkan generasi muda yang meninggalkan daerah asalnya dan menyebabkan lesunya industri setempat. Selain itu, konsepsi yang ditekankan dalam program ini, bahwa yang penting bukan hanya kemakmuran dari segi ekonomi (Gros National Product) tetapi juga kepuasan batin (Gros National Satisfaction) masyarakat setempat [3].

Tabel 1 Parameter analisis penerapan OVOP.

\begin{tabular}{|c|c|c|c|}
\hline No & Parameter Umum & Parameter Khusus & \\
\hline 1 & Tujuan & & \\
\hline \multirow[t]{4}{*}{2} & Inisiator OVOP & Pemerintah & Top-down \\
\hline & & & Bottom-up \\
\hline & & Masyarakat & \\
\hline & & Lembaga Swadaya Masyarakat & \\
\hline \multirow[t]{4}{*}{3} & Pihak yang terlibat selain & Pemerintah & \\
\hline & inisiator dan masyarakat & Sektor swasta & \\
\hline & & Universitas & \\
\hline & & Institusi lainnya & \\
\hline \multirow[t]{4}{*}{4} & Sumber pendanaan & Pemerintah & \\
\hline & & Masyarakat & \\
\hline & & LSM/LPSM & \\
\hline & & Lain-lain & \\
\hline 5 & Tahap-tahap pelaksanaan & & \\
\hline \multirow[t]{3}{*}{6} & $\begin{array}{l}\text { Bentuk partisipasi dalam } \\
\text { menentukan produk }\end{array}$ & Pemerintah & \\
\hline & & Tim Ahli (Konsultan/JETRO/dll) & \\
\hline & & Masyarakat (Fourm/Diskusi/ Ketua/dll) & \\
\hline \multirow[t]{11}{*}{7} & Desain & Ide desain & $\begin{array}{l}\text { Pengrajin } \\
\text { Desainer }\end{array}$ \\
\hline & & Ciri-ciri desain & Lokal \\
\hline & & & Trend \\
\hline & & Asal bahan/material & Lokal \\
\hline & & & Dari luar daerah \\
\hline & & Teknik produksi & Tradisional \\
\hline & & & Modern \\
\hline & & & Campuran \\
\hline & & Produk akhir & \\
\hline & Desainer & Latar belakang keilmuan & \\
\hline & & Pengalaman mendesain & \\
\hline \multirow[t]{4}{*}{8} & Bentuk pendampingan & Pelatihan & \\
\hline & & Workshop & \\
\hline & & Seminar & \\
\hline & & Lain-lain & \\
\hline \multirow[t]{3}{*}{9} & Jalur pemasaran (Promosi) & Nasional & \\
\hline & & Internasional & \\
\hline & & Internet/Majalah/Pameran/lain-lain & \\
\hline
\end{tabular}


Konsep One Village One Product (OVOP) sejak tahun 2006 mulai dipelajari dan diadopsi oleh berbagai negara, khususnya di Asia. OVOP diterapkan pada umumnya untuk menyelesaikan permasalahan kesenjangan sosial dan ekonomi yang terjadi antara desa dan kota di negara-negara Asia [4]. Selain itu, OVOP juga mulai dipelajari oleh negara-negara di Afrika terutama sebagai salah satu solusi bagi daerah-daerah miskin yang masih sangat bergantung pada pemerintah pusatnya. Pada bagian ini dipaparkan mengenai penerapan OVOP di negara-negara Asia yang telah dimulai lebih dulu dibandingkan dengan OVOP di Indonesia. Negara-negara yang mengadopsi OVOP di Asia diantaranya adalah Thailand (One Tambon One Product), Taiwan (One Town One Product), Malaysia (Satu Distrik Satu Industri), Filipina (One Town One Product), dan Kamboja (One Village One Product).

Pembandingan antar OVOP dalam penelitian ini juga akan dilakukan terhadap negara-negara tersebut dengan pelaksanaan program yang dilaksanakan oleh Pemerintah Republik Indonesia melalui Kementerian Perindustrian. Pembandingan akan dilakukan terhadap beberapa faktor terkait pelaksanaan OVOP dan akan ditampilkan pada Tabel 1.

Hasil analisis penerapan OVOP yang telah dipaparkan dirangkum dalam tabel di atas yang berisikan faktor-faktor utama dan pendukung yang ditemui dalam penerapan OVOP di negara lainnya. Faktor-faktor ini yang akan digunakan sebagai parameter dalam tahap penelitian selanjutnya, yaitu survey lapangan mengenai penarapan OVOP di daerah studi kasus Plered, Purwakarta.

\section{$4 \quad$ Hasil Analisis Penerapan OVOP di Plered, Purwakarta}

Pemerintah Indonesia melaksanakan program OVOP sebagai salah satu upaya untuk memajukan potensi industri kecil dan menengah di daerah [5]. Dengan tujuan ini, pelaksanaan program OVOP masih difokuskan hanya pada pengrajin dan pengusaha pada suatu daerah.

Dengan mengambil pelajaran dari penerapan OVOP di berbagai negara, diharapkan penerapan OVOP di Indonesia akan menemukan bentuk yang sesuai dengan kebutuhan daerah. Dengan demikian dapat diketahui kesesuaian antara konsep dasar OVOP dengan pelaksanaan OVOP yang dilaksanakan di Indonesia baik secara teori maupun pelaksanaan di lapangan.

Dikaitkan dengan prinsip-prinsip mendasar OVOP, program OVOP yang dilaksanakan oleh pemerintah memiliki perbedaan yang cukup mendasar. Prinsip pertama yaitu Local but Global yang bermakna menghasilkan produk atau jasa yang bernilai lokal dan dapat diterima secara global dalam dalam prinsip OVOP, dilaksanakan dengan cara meningkatkan kualitas produk melalui 
proses pelatihan teknis peningkatan mutu produksi dan desain [6]. Hasil akhir pelatihan tidak mengindikasikan adanya peningkatan dalam produksi produk yang dapat diterima secara global.

Prinsip dasar kedua OVOP yaitu Self reliance and creativity yang bermakna memanfaatkan potensi yang dimiliki secara kreatif dengan usaha-usaha yang mandiri sudah cukup terlihat dalam pelaksanaan OVOP di Plered. Dengan memanfaatkan potensi sumber daya alam dan sumber daya manusia yang telah lama dimanfaatkan oleh masyarakat Plered dalam kehidupan sehari-hari, melalui program OVOP mendapatkan dukungan yang lebih besar dari pemerintah.

Prinsip ketiga yaitu Human resource development memiliki makna mengembangkan potensi masyarakat agar memiliki semangat untuk kreatif dan mampu menghadapi tantangan. OVOP sebagai program pemerintah tidak difokuskan pada pengembangan potensi masyarakat daerah secara menyeluruh sehingga semangat OVOP seolah-olah hanya diperkenalkan pada peserta program, yaitu pengrajin dan pengusaha saja.

Pada dasarnya pelaksanaan OVOP di Plered tidak sesuai dengan prinsip mendasar OVOP yang seharusnya selalu ada dalam penerapan OVOP. Ketidaksesuaian ini dapat dikurangi apabila seluruh langkah pelaksanaan program OVOP yang sudah disusun oleh pemerintah, sepenuhnya dilaksanakan dengan penuh tanggung jawab. Bagaimanapun, program yang bersifat top-down pasti akan memerlukan proses pengawasan dan evaluasi yang terus menerus agar tujuan utama di lapangan dapat tercapai.

\section{$5 \quad$ Rekomendasi}

Berdasarkan hasil evaluasi dan analisis yang telah dilakukan pada bagian sebelumnya maka dapat disusun rekomendasi untuk pelaksanaan OVOP di Plered di masa yang akan datang. Rekomendasi yang diberikan adalah sebagai berikut:

1. Dalam menentukan bentuk pembinaan yang akan diberikan kepada pengrajin, bukan hanya melalui analisa permasalahan yang kemudian didiskusikan di forum koordinasi, tetapi juga dengan mendengarkan aspirasi masyarakat terhadap hal-hal yang sebenarnya dibutuhkan untuk mengembangkan potensi yang dimiliki [7].

2. Menghindari pemberian dana yang sama rata kepada pengrajin atau pengusaha yang tidak memiliki kemauan dan motivasi untuk mandiri dengan pengrajin atau pengusaha yang memiliki keinginan kuat untuk mandiri. 
3. Prosedur pemberian dana lebih diperketat sejak awal melalui proses seleksi berdasarkan klasifikasi tertentu.

4. Titik berat materi pelatihan yang diberikan oleh konsultan sebaiknya disesuaikan dengan kebutuhan masing-masing pengrajin atau pengusaha, sehingga menjadi lebih efektif dan mudah diaplikasikan dalam upaya pemajuan usahanya.

5. Pengrajin dan pengusaha dibangun kesadarannya akan pentingnya menjadi mandiri bagi seluruh masyarakat, bukan hanya sekedar memajukan usahanya masing-masing. Perlu dibangun kesadaran akan, agar tidak lagi bergantung pada bantuan pemerintah dalam memajukan potensi yang telah mereka miliki [8].

6. Pengrajin dan pengusaha dibangun kesadaran akan pentingnya terus berkreasi dalam mengembangkan potensi produk, baik secara desain, maupun secara teknik produksi dan tidak terus menerus tergantung pada desain yang diberikan pembeli.

7. Pengrajin dan pengusaha harus memahami dengan pasti pasar luar negeri yang akan dituju, sehingga berbagai pengetahuan mengenai desain, selera dan trend akan target pasar menjadi sangat penting.

8. Pembuatan desain yang sama sekali baru harus dengan memperhatikan selera pasar yang akan dituju, sehingga unsur kebaruan yang ditampilkan tetap dapat diterima oleh pasar.

9. Pengembangan desain berdasarkan permintaan perantara (buyer) harus dibatasi. Desainer memiliki peran yang sangat signifikan dalam mengembangkan desain yang dapat mempertahankan nilai-nilai tradisional.

10. Program pendampingan dititikberatkan pada pengembangan desain tidak terbatas pada proses pelatihan teknis saja, tetapi juga pendampingan oleh desainer professional yang berfungsi sebagai 'bank' desain dan konsultan.

11. Pemerintah membantu bukan hanya membuka jalur pemasaran melalui pengikutsertaan produk pada pameran, tetapi juga menyediakan pasar, dengan bekerja sama dengan institusi pemerintahan lainnya, atau pihak swasta.

12. Pelaksanaan rangkaian program lebih efektif dalam setiap tahun, termasuk tahap monitoring dan evaluasi.

Selain rekomendasi di atas yang ditujukan untuk pelaksanaan OVOP di Plered, kajian terhadap pelaksanaan OVOP di berbagai negara dan di Indonesia juga menghasilkan rekomendasi yang dapat digunakan sebagai pertimbangan untuk melaksanakan OVOP untuk mengembangkan potensi kerajinan di wilayah lain di Indonesia. Rekomendasi yang dihasilkan sebagai berikut:

1. Memanfaatkan semua prinsip OVOP bukan hanya sebagai sebuah pendekatan untuk memajukan potensi IKM tetapi juga sebagai sebuah upaya untuk membangun suatu daerah [9]. 
2. Melibatkan masyarakat daerah secara meluas dalam melakukan identifikasi permasalahan yang dihadapi oleh IKM dan masyarakat agar seluruh masyarakat merasa memiliki dan terlibat dalam pelaksanaan program [10].

3. Program harus mampu memunculkan motivasi masyarakat untuk mandiri, dengan cara membuat pengklasifikasian yang lebih spesifik mengenai pengrajin atau pengusaha yang akan diikutsertakan dalam program OVOP agar hanya pengrajin pengrajin atau pengusaha yang memenuhi persyaratan saja yang akan diikutsertakan program OVOP.

4. Proses seleksi yang dilaksanakan harus lebih ketat dan bersifat fleksibel. Seleksi yang ketat berarti membuat sistem pengklasifikasian yang dapat menyeleksi pengrajin atau pengusaha yang memiliki keterampilan yang baik, manajemen usaha yang sehat, kemandirian, dan motivasi untuk maju dan memajukan masyarakatnya. Sementara seleksi yang bersifat fleksibel artinya proses seleksi dapat dilakukan berdasarkan pengajuan yang dilakukan oleh masyarakat. Artinya masyarakat yang merasa memenuhi persyaratan tersebut dapat mengajukan dirinya untuk diseleksi untuk mengikuti program OVOP.

5. Proses seleksi akan menjadi motivasi bagi pengrajin maupun pengusaha untuk dapat terpilih. Sebagai reward, pengrajin dan pengusaha yang terpilih melalui proses seleksi akan dijadikan peserta yang menerima pembinaan dan bantuan dana melalui program OVOP.

6. Titik berat materi pembinaan, jangka waktu, dan periode pelaksanaan OVOP disesuaikan dengan kebutuhan masing-masing pengrajin atau pengusaha yang terpilih.

7. Penyusunan program yang tidak hanya dititikberatkan pada pengembangan teknis produksi, desain dan pemasaran, tetapi juga harus dapat lebih membangun motivasi dan kesadaran masyarakat untuk lebih kreatif dalam memanfaatkan potensi yang dimiliki dalam menghasilkan produk yang baik dan dapat bersaing di pasar global [11].

8. Program disusun sesuai dengan kebutuhan, baik materi maupun rentang waktu pelaksanaan. Program disusun berorientasi pada target atau tujuan pengembangan (target-oriented) sehingga harus bersifat dinamis dalam pelaksanaannya.

9. Pengembangan potensi sumber daya manusia dikhususkan pada peningkatan keahlian dalam membuat kerajinan. Pembinaan diberikan kepada masyarakat, khususnya yang berusia muda. Hal ini berkaitan erat dengan keberlanjutan industri kerajinan yang dapat terancam apabila masyarakat yang berusia muda tidak memiliki keahlian yang sama dengan leluhurnya [12].

10. Pengembangan desain merupakan faktor penentu dalam keberhasilan program. Desain kerajinan yang dikembangkan harus melibatkan desainer professional yang memiliki kemampuan untuk membuat desain yang dapat mencerminkan nilai-nilai tradisional dari kerajinan yang dikembangkan. 
Selain itu, desainer juga harus memiliki kemampuan untuk membaca target pasar dari produk kerajinan tersebut.

11. Pemerintah bukan hanya membuka jalur pemasaran melalui pengikutsertaan produk pada pameran, tetapi juga menyediakan pasar, dengan bekerja sama dengan institusi pemerintahan lainnya, atau pihak swasta.

12. Pelaksanaan monitoring dan evaluasi dilakukan secara rutin, termasuk pengawasan kegiatan pemasaran yang dilakukan setelah proses pembinaan untuk memantau perkembangan yang terjadi.

\section{$6 \quad$ Kesimpulan}

Pemerintah Indonesia melaksanakan program OVOP sebagai salah satu upaya untuk memajukan potensi industri kecil dan menengah kerajinan di daerah. Memajukan potensi produk kerajinan tidak hanya bertujuan untuk memajukan perekonomian pengrajinnya, tetapi juga melestarikan nila-nilai tradisional yang dikandung dalam produk, seperti keahlian yang diturunkan dari generasi ke generasi. Penerapan OVOP dalam rangka memajukan industri kerajinan memerlukan adanya strategi khusus yang sesuai dengan prinsip mendasar OVOP dan dapat menyelesaikan permasalahan yang dihadapi oleh industri kerajinan.

Pengejawantahan prinsip dasar OVOP yang dilaksanakan di setiap negara berbeda-beda. Melalui upaya yang dilakukan selama bertahun-tahun, setiap negara berupaya untuk menemukan cara-cara yang paling sesuai untuk memunculkan semangat OVOP dalam program yang dilaksanakannya. Dengan mempelajari berbagai cara ini, diharapkan Indonesia juga dapat menemukan bentuk OVOP yang paling sesuai untuk diterapkan khususnya untuk memajukan industri kerajinan.

Dengan memetakan aspek-aspek yang manjadi faktor penting dalam pelaksanaan OVOP, maka dapat disusun sebuah strategi bagi pelaksanaan OVOP di Indonesia yang sesuai dengan semangat OVOP. Penelitian ini bertjuan mencari aspek-aspek tersebut melalui studi komparasi dengan pelaksanaan OVOP di Jepang, serta beberapa negara lain di Asia, termasuk di Indonesia. Aspek-aspek penentu keterlaksanaan OVOP yang terpetakan dalam penelitian ini adalah sebagai berikut:

1. Tujuan pelaksanaan

2. Inisiator OVOP

3. Pihak yang terlibat, selain inisiator dan masyarakat

4. Sumber pendanaan

5. Tahap-tahap pelaksanaan

6. Bentuk partisipasi dalam menentukan produk unggulan 
7. Desain dan desainer

8. Bentuk pendampingan

9. Jalur pemasaran

Dalam penelitian ini pula ditemukan adanya ketidaksesuaian dalam penerapan prinsip-prinsip tersebut dalam penerapan OVOP. Hal tersebut ditunjukkan dalam poin-poin sebagai berikut:

1. Prinsip local but global memiliki sedikit kesesuaian dengan penerapan program OVOP di Plered, hal ini berkaitan dengan pengembangan potensi kerajinan gerabah dan keramik hias yang menjadi fokus utama pemerintah dalam program tersebut. Pengembangan produk melalui program OVOP difokuskan pada pengembangan IKM kerajinan agar dapat menghasilkan produk yang bermuatan lokal dan dapat bersaing di pasar global. Meskipun demikian kemampuan untuk bersaing di pasar global yang sebenarnya dari produk yang dihasilkan belum dapat dilihat.

2. Prinsip self-reliance and creativity tidak teridentifikasi dalam penerapan OVOP di Plered. Hal ini disebabkan karena program OVOP yang bersifat top-down dari pemerintah pusat dan sosialisasi dari program OVOP yang relatif baru (sejak 2008). Program OVOP yang disusun oleh pemerintah juga tidak menitikberatkan pada pengembangan motivasi dan kreativitas pengrajin/pengusaha. Program OVOP juga tidak dititikberatkan kepada pengembangan kemandirian atau pemberdayaan masyarakat setempat.

3. Prinsip ketiga yaitu human resources development juga tidak ditemukan dalam pelaksanaan program OVOP di Plered. Hal ini ditunjukkan dengan tidak adanya pembinaan terhadap masyarakat setempat selain pengrajin/pengusaha. Selain itu, masyarakat juga tidak dilibatkan secara meluas dalam program OVOP.

Hal di atas menunjukkan sebuah kesimpulan dari pelaksanaan program OVOP di Plered yang belum sesuai dengan prinsip-prinsip OVOP secara keseluruhan. Oleh karena itu disusun sebuah rekomendasi bagi penerapan OVOP di Plered di masa yang akan datang serta rekomendasi bagi pelaksanaan OVOP di Indonesia secara umum. Rekomendasi bagi pelaksanaan OVOP ditujukan kepada pemerintah sebagai pemangku kebijakan, tim ahli yang terlibat dalam pelaksanaan OVOP dalam hal ini adalah desainer, pengrajin/pengusaha, serta masyarakat wilayah tersebut.

Berikut ini adalah rekomendasi bagi pelaksanaan OVOP di Plered secara ringkas.

1. Pemerintah

a. Melibatkan masyarakat Plered secara meluas pada tahap analisa awal dalam menentukan bentuk pembinaan yang akan diberikan kepada 
pengrajin, bukan hanya melalui analisa permasalahan yang didiskusikan di forum koordinasi, tetapi juga dengan mendengarkan aspirasi masyarakat terhadap hal-hal yang sebenarnya dibutuhkan untuk mengembangkan potensi yang dimiliki.

b. Lebih selektif dalam tahap penjaringan peserta (pengrajin/pengusaha) dan menghindari pemberian dana yang sama rata kepada pengrajin atau pengusaha yang tidak memiliki kemauan dan motivasi untuk mandiri dengan pengrajin atau pengusaha yang memiliki keinginan kuat untuk mandiri.

c. Penyusunan materi pendampingan yang disesuaikan dengan kebutuhan peserta. Titik berat materi pelatihan yang diberikan oleh konsultan sebaiknya disesuaikan dengan kebutuhan masing-masing pengrajin atau pengusaha, sehingga menjadi lebih efektif dan mudah diaplikasikan dalam upaya pemajuan usahanya.

d. Pemerintah membantu bukan hanya membuka jalur pemasaran melalui pengikutsertaan produk pada pameran, tetapi juga menyediakan pasar, dengan bekerja sama dengan institusi pemerintahan lainnya, atau pihak swasta.

e. Pelaksanaan rangkaian program lebih efektif dalam setiap tahun, termasuk tahap monitoring dan evaluasi.

2. Tim ahli/desainer

a. Lebih berperan sebagai 'bank' desain dan konsultan yang selalu memiliki ketersediaan desain baru yang dapat dibuat oleh pengrajin.

b. Memiliki pemahaman lebih terhadap pengembangan desain untuk IKM kerajinan sebagai sebuah upaya untuk melestarikan nilai tradisional sekaligus memenuhi kebutuhan pasar.

c. Pemanfaatan organisasi masyarakat (Koperasi atau Kelompok Kerja) dan institusi yang sudah terbentuk (UPTD dan sebagainya) dalam menjalankan pendampingan maupun pelatihan.

3. Pengrajin/pengusaha

a. Melakukan pembatasan terhadap pembuatan desain yang didasarkan pada permintaan buyer dan lebih kreatif dalam memanfaatkan potensi yang dimiliki dalam mengembangkan desain

b. Memahami peran desain sebagai sebuah upaya untuk melestarikan nilainilai tradisional dari kerajinan sekaligus untuk memenuhi keinginan pasar

c. Lebih memanfaatkan komunitas-komunitas yang telah terbentuk untuk dapat melaksanakan OVOP yang dapat melibatkan masyarakat Plered secara meluas

d. Peningkatan keahlian atau keterampilan bagi tenaga kerja serta bagi masyarakat usia muda untuk mengantisipasi keberlanjutan usaha kerajinan di masa yang akan datang 
4. Masyarakat

a. Keterlibatan masyarakat sejak awal dalam pelaksanaan program OVOP

b. Meningkatkan motivasi untuk mandiri dan menjadi bermanfaat terhadap masyarakat Plered

c. Meningkatkan motivasi untuk mau berpikir secara kreatif dalam memanfaatkan potensi yang dimiliki masyarakat dan lingkungan Plered

d. Pembinaan masyarakat usia muda untuk mengantisipasi keberlanjutan program OVOP yang dilaksanakan di Plered.

Selain rekomendasi bagi pelaksanaan program OVOP di Plered, dalam penelitian ini juga dihasilkan sebuah rekomendasi bagi pelaksanaan OVOP dengan potensi kerajinan di wilayah lain di Indonesia. Rekomendasi juga ditujukan kepada pemerintah, tim ahli/desainer, pengrajin/pengusaha, dan masyarakat wilayah tersebut. rekomendasi dirumuskan sebagai berikut:

1. Pemerintah

a. Agar dapat melaksanakan program OVOP bukan sekedar untuk menyelesaikan permasalahan yang dihadapi IKM industri kerajinan, tetapi juga sebagai sebuah pendekatan dalam pembangunan daerah

b. Melakukan tahap seleksi dalam memilih pengrajin/pengusaha yang akan dibina secara lebih selektif dan fleksibel

c. Menjadikan tahap pendampingan dan pembinaan sebagai sebuah reward bagi pengusaha/pengrajin yang terpilih

d. Menjadikan program OVOP sebagai program yang berorientasi pada target, sehingga pelaksanaannya harus dinamis dan cepat tanggap dalam menyelesaikan berbagai permasalahan yang dihadapi di lapangan

e. Membuka jalur pemasaran dan menyediakan pasar melalui kerjasama dengan berbagai pihak termasuk dengan pihak swasta

f. Menjalankan fungsi monitoring dan evaluasi secara komprehensif

2. Tim ahli/desainer

a. Lebih berperan sebagai 'bank' desain dan konsultan

b. Pemahaman lebih terhadap pengembangan desain untuk IKM kerajinan sebagai sebuah upaya untuk melestarikan nilai tradisional sekaligus memenuhi kebutuhan pasar

c. Pemanfaatan organisasi masyarakat dan institusi yang sudah terbentuk dalam menjalankan pendampingan maupun pelatihan

3. Pengrajin/pengusaha

a. Melakukan pembatasan terhadap pembuatan desain yang didasarkan pada permintaan buyer dan lebih kreatif dalam memanfaatkan potensi yang dimiliki dalam mengembangkan desain 
b. Memahami peran desain sebagai sebuah upaya untuk melestarikan nilainilai tradisional dari kerajinan sekaligus untuk memenuhi keinginan pasar

c. Lebih memanfaatkan komunitas-komunitas yang telah terbentuk untuk dapat melaksanakan OVOP yang dapat melibatkan masyarakat wilayah tersebut secara meluas

d. Peningkatan keahlian atau keterampilan bagi tenaga kerja serta bagi masyarakat usia muda untuk mengantisipasi keberlanjutan usaha kerajinan di masa yang akan datang

4. Masyarakat

a. Keterlibatan masyarakat sejak awal dalam pelaksanaan program OVOP

b. Meningkatkan motivasi untuk mandiri dan menjadi bermanfaat terhadap masyarakat secara meluas

c. Meningkatkan motivasi untuk mau berpikir secara kreatif dalam memanfaatkan potensi yang dimiliki masyarakat dan lingkungannya

d. Pembinaan masyarakat usia muda untuk mengantisipasi keberlanjutan program OVOP yang dilaksanakan di wilayah tersebut.

Dari penelitian yang telah dilakukan juga ditemukan adanya sebuah faktor penting bagi pelaksanaan OVOP di Indonesia. Mengingat bahwa program OVOP bersifat top-down, maka perlu suatu upaya lebih dalam menjadikan OVOP dapat dipahami dan dimaknai oleh masyarakat suatu wilayah sebagai sebuah spirit atau semangat. Hal ini dapat diupayakan dengan cara mencari tokoh sentral dalam komunitas tersebut. Tokoh yang dimaksud merupakan tokoh masyarakat yang didengar dan dihormati oleh masyarakat setempat, mau bekerjasama dengan pemerintah, serta memiliki kesadaran terhadap pentingnya membangun masyarakat di sekitarnya. Dengan adanya tokoh semacam ini dalam suatu masyarakat, maka memungkinkan proses sosialisasi OVOP yang lebih efektif dan tidak semata-mata hanya sebagai sebuah program pemerintah.

\section{Referensi}

[1] Departemen Perindustrian. 2007. Membangun Daya Saing Industri Daerah: Dengan Pendekatan Kompetensi Inti Industri Daerah, Jakarta: Departemen Perindustrian.

[2] Sugiharto, Y. \& Rizal, S. 2008. Gerakan OVOP sebagai Upaya Peningkatan Pembangunan Daerah, Jakarta: Benchmark.

[3] Hiramatsu \& Morihiko. 2009. Opening Speech OVOP International Seminar in Bali, Indonesia.

[4] Murayama, H. 2009. A Case Study Archive of OVOP for Regional Development, The $6^{\text {th }}$ OVOP International Seminar, Bali-Indonesia.

[5] Daya Cipta Dianrancana, PT. 2010. Laporan Modul Pelatihan Jasa Konsultansi Peningkatan Teknologi dan Mutu Produk IKM Kerajinan 
gerabah/Keramik Hias dalam Rangka Pengembangan IKM Kerajinan melalui OVOP Purwakarta, Jawa Barat, Jakarta: Kementerian Perindustrian.

[6] Kementerian Perindustrian. 2010. Pedoman Umum dan Petunjuk Teknis Pengembangan IKM melalui Pendekatan Satu Desa Satu Produk (One Village One Product-OVOP), Jakarta: Dirjen IKM Kementerian Perindustrian.

[7] Friedmann, J. 1992. Empowerment: The Politics of Alternative Development, Cambridge: Blackwell.

[8] Hikmat, H. 2001. Strategi Pemberdayaan Masyarakat, Bandung: Humaniora Utama Press.

[9] Roesmidi, M.M. \& Risyanti, R. 2008. Pemberdayaan Masyarakat, Bandung: Alqaprint Jatinangor.

[10] Mikkelsen, B. 2003. Metode Penelitian Partisipatoris dan Upaya-upaya Pemberdayaan, Jakarta: Yayasan Obor Indonesia.

[11] Stenning, N. \& Miyoshi, K. 2008. Networking, Knowledge and Community Capacity Development, Ritsumeikan Asia Pacific University.

[12] Suzuki, N. 2002. Development Strategy Formulation for Artisan Craft Promotion: The Effective Promotion for Regional Development in Developing Countries Part I \& II, Chiba University. 